\title{
Clinical Biomarkers for Diagnosis of Damages in Individuals with Long-Term Exposure to X-Rays
}

\author{
Khurram Rehman1, Ghulam Mustafa1, Muzammil Ahmad Khan², Zahid Rauf3, Naqab Khan4 and Samiullah Khan²
}

\begin{abstract}
Objective: To determine altered manifestation of plasma proteins in X-rays technicians who are regularly exposed to low doses of radiations over a long period during their job.

Study Design: Descriptive study.

Place and Duration of Study: District Headquarters Hospital and Mufti Mahmood Memorial Teaching Hospital; from January 2017 to January 2018.

Methodology: The study enrolled 70 individuals consisting of $50 \mathrm{X}$-ray technicians working 8 to 12 hours/day for five days per week and 20 unexposed healthy controls. The serum protein expression pattern (concentrations of various serum proteins) was evaluated through cellulose acetate electrophoresis and serum antioxidant status was measured through ferric reducing ability of plasma (FRAP) assay.

Results: The antioxidant assay showed significantly low trolox-equivalent antioxidant capacity (TEAC) status and FRAP value in $X$-ray technicians as compared to controls $(p<0.001)$. Analysis of serum protein demonstrated a significantly reduced concentrations of albumin $(p<0.001)$ and elevated level of the $\gamma$-globulins $(p<0.001)$, while other globulins fractions like $\alpha 1$ and $\beta$ remain unchanged. There was a strong negative correlation $(p<0.001)$ according to Pearson coefficient $\left(r=87 \% \%^{(-)}\right)$between albumin and $\gamma$-globulins fraction. Whereas, a positive correlation $(p<0.001)\left(r=46 \%^{(+)}\right)$ between alpha 1 globulin and albumin fraction was observed. A correlation between other globulin fractions and albumin was found statistically significant $(\mathrm{p}<0.001)$.

Conclusion: Elevated serum gamma globulins may be a potential protein biomarker for triage and detection of X-radiation induced damages.
\end{abstract}

Key Words: Biomarkers, Cellulose acetate electrophoresis, Globulins, Occupational exposure, Alpha globulin.

\section{INTRODUCTION}

X-rays are a type of high energy (100 eV to $100 \mathrm{KeV})$ radiations with a wavelength ranging from 0.01 to 10 nanometers, can cause cellular dysfunctions through ionization and genetic mutation upon interaction.1,2 $\mathrm{X}$-radiations originating from diagnostic tools (computed tomography, fluoroscopy and conventional X-ray radiography) are widely used in medical practice. Beside a number of medical benefits, X-ray imaging poses a high risk of the induction of cancer in the active workers. ${ }^{2}$

X-rays have been classified as carcinogenic by the World Health Organization's International Agency for Research on Cancer. Intervention radiology (IR) produces free radicals by liberating electron from water molecule

1 Department of Pharmaceutical Chemistry, Faculty of Pharmacy, Gomal University, Dera Ismail Khan, KPK, Pakistan

2 Gomal Center of Biochemistry and Biotechnology, Gomal University, Dera Ismail Khan, KPK, Pakistan

3 Department of Statistics, Gomal University, Dera Ismail Khan, KPK, Pakistan

4 Department of Basic Medical Sciences, Faculty of Pharmacy, Gomal University, Dera Ismail Khan, KPK, Pakistan

Correspondence: Dr. Samiullah Khan, Gomal Center of Biochemistry and Biotechnology, Gomal University,

Dera Ismail Khan, KPK, Pakistan

E-mail:drsukhan@gu.edu.pk

Received: April 02, 2018; Revised: November 25, 2018; Accepted: March 18, 2019 which can cause irreversible damage to the cells and tissues of particular organ.3,4 The longer exposure causes cancer due to excessive formation of reactive oxygen species (ROS) and nitric oxide (NO) in the body. ${ }^{5}$ Antioxidant systems of the body protects the cells against damage initiated by free radicals, this system may be strengthened by the administration of antioxidant compounds, i.e. vitamin $\mathrm{C}$ and $\mathrm{E} .6$

There are more than 500 different proteins in human blood which perform various functions, e.g. maintaining osmotic pressure, metabolic and hemostatic functions. Among these blood proteins, albumin, alpha 1, alpha 2, beta and gamma globulins are important subsets. One of the largest proteins found in blood is albumin which constitutes $60 \%$ of total blood proteins, is responsible for $80 \%$ of osmotic pressure and transportation of substances, maintaining plasma $\mathrm{pH}$, blood viscosity and biophysical nature of blood flow. 5-7

The interaction of radiations either causes ionization of DNA or other cellular components or radiolysis of cellular water through ROS that may lead to the oxidation of nucleic acid and other cellular components. ${ }^{8-10}$ In in vivo studies, it is very difficult to assess the presence of free radicals directly due to their short life time. Thus one of the indirect measurements is made possible by analysis of changes induced by those radicals at plasma protein level. Irradiation also causes protein degradation and 
protein structure modifications. ${ }^{8}$ An organism responds to radiation exposure by altering the expression or post translation modifications of proteins in cell, tissues or organic fluids of the body like serum, plasma or urine. So protein expression profiling in these specimen can be very useful to evaluate the detrimental effect of radiation exposures for long period of time.9,10 Total serum proteins estimation is an important diagnostic technique to assess the health status of the organism. There are two major fractions of serum proteins (albumin and globulins) which can be separated by cellulose acetate-based electrophoresis. Globulins are a relatively smaller faction of total serum proteins which are sub-divided into 5 components (alpha1, alpha2, beta1, beta2 and gamma). The relative quantities of this subset are primarily studied in serum protein electrophoresis interpretation.

The aim of this study was to evaluate the $X$-rays-induced oxidative stress and its effects on serum proteins (albumin, $\alpha 1, \alpha 2, \beta 1, \beta 2$ and $\gamma$-globulins) expression in occupational operators of radio-therapeutic equipment.

\section{METHODOLOGY}

It was a comparative cross-sectional study conducted from January 2017 to Jan 2018. The current study was conducted according to the ethical guidelines and institutional approval of board of study of Gomal University, vide letter No. 4587-94.

The present study was carried out on 70 subjects which included 50 workers from radiology units of District Headquarters Hospital and Mufti Mahmood Memorial Teaching Hospital, Dera Ismail Khan, KPK, Pakistan and 20 healthy controls that had never been exposed to $\mathrm{X}$-radiation. The study enrolled those $\mathrm{X}$-rays technicians who worked for 48 hours to 72 hours per week. All subjects were enrolled after taking written inform consent. Venous blood samples (5 mls) were collected in plain blood collection tubes from all subjects between 9.0 and 11.0 a.m. All the serum samples were labelled with specific code to hide the identity of subjects. This study did not include those subjects who were suspected of having gross anemia, genetic disorders, diabetes mellitus, cardiopulmonary diseases, viral or bacterial infection, autoimmune diseases, malignancy or any medicine intake. FRAP assay (ferric reducing ability of plasma) was performed on blood serum to estimate the oxidative stress in X-rays exposed individuals. ${ }^{11}$ The method is based on the formation of blue colored ferrous-tripyridyltriazine ( $\mathrm{Fe}^{2+}$-TPTZ) complex by reduction of ferric $\left(\mathrm{Fe}^{3+}\right)$ to ferrous $\left(\mathrm{Fe}^{2+}\right)$ ion at low $\mathrm{pH}$. The optical density (OD) value was measured at $593 \mathrm{~nm}$ wavelength.

FRAP value was calculated by equation:

$$
\text { FRAP } \mu \text { Mole value }=\frac{0-\text { to } 4-\min \triangle \mathrm{A}_{593} \mathrm{~nm} \text { test sample }}{0-\text { to } 4-\min \triangle \mathrm{A}_{593} \mathrm{~nm} \text { test standard }} \times \mathrm{FRAP}_{\text {std }} \mu \mathrm{M}
$$

The serum protein electrophoresis was performed on cellulose acetate strips. For serum protein electro- phoresis, the strips were socked in ready-made buffer $(\mathrm{pH} 8.6)$ and placed between two Whatman No. 1 filter papers to remove the extra buffer.

Pearson correlation coefficient was used to determine the linear strength of interdependency. The coefficient of correlation with value more than 0.7 was set a value for strong relationship and less coefficient for a moderate interdependency. For unit change in the regress and was observed with the help of linear regression analyses in the presence of studied regressors in the mechanism observed. The descriptive statistics and inferential finding's significance was observed through t-statistics (student t-test for two sided comparison). For statistical analysis, SPSS version 20 (IBM, USA) was used. The statistical significance was observed on significant value set at $1 \%$ with $p$-values observed.

\section{RESULTS}

In this study, there was no statistically significant difference in ages of occupationally exposed radiology workers (36.98 \pm 8.07 years) and controls (36.80 \pm 7.78 years). The mean duration of X-radiation exposure was 57.12 \pm 9.25 hours per week.

The mean values of Trolox equivalent antioxidant capacity (TEAC) of serum in exposed group was significantly lower $40.99 \pm 13.34 \mu \mathrm{g} / \mathrm{ml}$ than control individuals 146.87 $\pm 18.41 \mu \mathrm{g} / \mathrm{ml}$ with $(\mathrm{p}<0.001$, Table I).

The serum protein electrophoresis revealed that total protein concentrations of exposed group were within normal range with the mean value $7.74 \pm 0.35 \mathrm{~g} / \mathrm{dl} v \mathrm{~s}$. $7.62 \pm 0.40 \mathrm{~g} / \mathrm{dl}$ in control group (Table I).

Those radiology technicians, who worked for 60 and 72 hours per week, showed significant decline in serum albumin levels, while normal albumin levels were observed in technicians who worked for 48 hours per week. The mean values and standard deviation of albumin percentages in exposed group was $57.53 \pm 5.56$ $\mathrm{g} / \mathrm{dl}$ as compared with control group $63.47 \pm 1.54 \mathrm{~g} / \mathrm{dl}$ (Figure 1, Table I).

The radiation exposed group showed serum alpha-1 globulin percentage within normal range $(2.0-3.5 \%)$. The mean values of alpha-1 globulins in radiation exposed and control groups were $2.42 \pm 0.41$ vs. 2.56 \pm 0.38 ( $p=0.61$, Figure 1, Table I).

The mean values and standard deviation of serum percentage of alpha-2 globulins in both exposed and control groups were $7.00 \pm 1.27 \%$ vs. $7.8 \pm 0.98 \%$. The radiation exposed group showed percentage of alpha-2 globulins within normal range $(5.4-10.7 \%), \quad(p=0.026$, Figure 1, Table I).

The result of serum electrophoresis revealed no abnormality in serum beta globulin percentage when compared with the normal values. The mean values of beta globulins levels in radiation exposed individuals 
Table I: Effects of X-radiation exposure on serum proteins and FRAP ability in human subjects with respect to duration.

\begin{tabular}{|c|c|c|c|c|c|}
\hline & \multicolumn{3}{|c|}{$\begin{array}{l}\text { Exposed Group ( } n=50) \\
\text { Duration of exposure (Hours per week) }\end{array}$} & \multirow[t]{2}{*}{ Control group $(n=20)$} & \multirow[t]{2}{*}{$\mathrm{p}$-value } \\
\hline & $48(n=23)$ & $60(n=12)$ & $72(n=15)$ & & \\
\hline $\operatorname{TEAC}(\mu \mathrm{g} / \mathrm{ml})$ & $52.37 \pm 8.84$ & $37.65 \pm 2.54$ & $26.21 \pm 6.23$ & $146.60 \pm 18.41$ & $<0.0001$ \\
\hline FRAP value $(\mu \mathrm{M})$ & $237.99 \pm 32.5$ & $180.93 \pm 13.51$ & $144.33 \pm 25.64$ & $585.15 \pm 67.66$ & $<0.0001$ \\
\hline Total protein $(\mathrm{g} / \mathrm{dl})$ & $7.61 \pm 0.36$ & $7.81 \pm 0.36$ & $7.90 \pm 0.24$ & $7.61 \pm 0.40$ & $<0.0001$ \\
\hline \multicolumn{6}{|l|}{ Albumin band } \\
\hline Low & - & 12 & 15 & - & $<0.0001$ \\
\hline Normal & 23 & - & - & 20 & \\
\hline High & - & - & - & & \\
\hline Mean \pm SD albumin (\%) & $63.22 \pm 2.98$ & $53.66 \pm 0.41$ & $52.55 \pm 1.17$ & $63.20 \pm 1.54$ & \\
\hline \multicolumn{6}{|l|}{ Alpha- 1 band } \\
\hline Low & - & - & - & - & 0.61 \\
\hline Normal & 23 & 12 & 15 & 20 & \\
\hline High & - & - & - & - & \\
\hline Mean \pm SD alpha1 (\%) & $2.23 \pm 0.34$ & $2.5 \pm 0.32$ & $2.62 \pm 0.37$ & $2.22 \pm 0.38$ & \\
\hline \multicolumn{6}{|l|}{ Alpha-2 band } \\
\hline Low & - & - & - & - & 0.026 \\
\hline Normal & 23 & 12 & 15 & 20 & \\
\hline High & - & - & - & - & \\
\hline Mean \pm SD alpha $2(\%)$ & $7.08 \pm 1.26$ & $7.04 \pm 1.17$ & $6.84 \pm 1.43$ & $7.8 \pm 0.98$ & \\
\hline \multicolumn{6}{|l|}{ Beta band } \\
\hline Low & - & - & - & - & 0.026 \\
\hline Normal & 23 & 12 & 15 & 20 & \\
\hline High & - & - & - & - & \\
\hline Mean \pm SD beta $(\%)$ & $10.97 \pm 2.01$ & $11.93 \pm 1.20$ & $11.86 \pm 1.38$ & $10.13 \pm 1.34$ & \\
\hline \multicolumn{6}{|l|}{ Gamma band } \\
\hline Low & - & - & - & - & $<0.0001$ \\
\hline Normal & 23 & - & - & 20 & \\
\hline High & - & 12 & 15 & - & \\
\hline Mean \pm SD gamma (\%) & $16.20 \pm 1.41$ & $19.18 \pm 0.41$ & $21.38 \pm 1.38$ & $15.56 \pm 1.04$ & \\
\hline Albumin / globulin (A/G) & & 1.498 & & 1.717 & $<0.0001$ \\
\hline
\end{tabular}

Table II: Correlation between serum proteins fractions of exposed subjects.

\begin{tabular}{l|c|c|c|c|c}
\hline & Albumin & Gamma & Alph1 & Alph2 & Beta \\
\hline Albumin & & & & & \\
Pearson correlation & 1 & $-.871^{* *}$ & $-.477^{* *}$ & .001 & $-.465^{* *}$ \\
Sig. (2-tailed) & - & .000 & .000 & .995 & .001 \\
$\mathrm{~N}$ & 50 & 50 & 50 & 50 & 50 \\
\hline Gamma & & & & & \\
Pearson correlation & $-.871^{* *}$ & 1 & $.438^{* *}$ & -.228 & .177 \\
Sig. (2-tailed) & .000 & - & .001 & .111 & .220 \\
$\mathrm{~N}$ & 50 & 50 & 50 & 50 & 50 \\
\hline Alpha 1 & & & & & \\
Pearson correlation & $-.477^{* *}$ & $.438^{* *}$ & 1 & .053 & .118 \\
Sig. (2-tailed) & .000 & .001 & - & .717 & .416 \\
N & 50 & 50 & 50 & 50 & 50 \\
\hline Alpha 2 & & & & & \\
Pearson correlation & .001 & -.228 & .053 & 1 & .081 \\
Sig. (2-tailed) & .995 & .111 & .717 & - & .575 \\
N & 50 & 50 & 50 & 50 & 50 \\
\hline Beta & & & & & \\
Pearson correlation & $-.465^{* *}$ & .177 & .118 & .081 & 1 \\
Sig. (2-tailed) & .001 & .220 & .416 & .575 & - \\
N & 50 & 50 & 50 & 50 & 50 \\
\hline
\end{tabular}

** Correlation is significant at the 0.01 level (2-tailed).

Note: Sig. (2-tailed): 2- tailed t-test was used.

N: Total subjects.

** Significant relationship at $p=0.01 \%$ or less. versus control groups were $11.44 \pm 1.68 \%$ vs. 11.13 $\pm 1.34 \%$ with ( $p=0.129$, Figure 1 , Table I).

Among the exposed groups, those subjects having 60 and 72 hours exposure time showed hypergammaglobulinemia (normal values $8.0 \%-18.0 \%$ ). The mean values and standard deviation of gamma globulins of serum in exposed groups and controls were 18.43 $\pm 2.57 \%$ vs. $15.56 \pm 1.04 \%$ ( $p<0.001$, Figure 1, Table I). In comparison to control group, significantly reduced albumin/globulin $(A / G)$ ratio was observed $(p<0.001)$ in X-rays exposed group (Table I).

Statistical analysis between albumin and gamma globulins showed a highly negative correlation. The linear simultaneous change in both serum proteins have statistically significant interdependence $(p<0.001)$. The correlation coefficient between albumin and gamma globulin was 0.871 with the inverse relationship $(p<0.001$, Table II).

The linear interdependence among alpha1 and gamma globulins $(r=50 \%)$ and alpha1 and albumin $(r=48 \%)$ are statistically significant $(p<0.001)$. The correlation coefficient for respective interdependency indicated a 

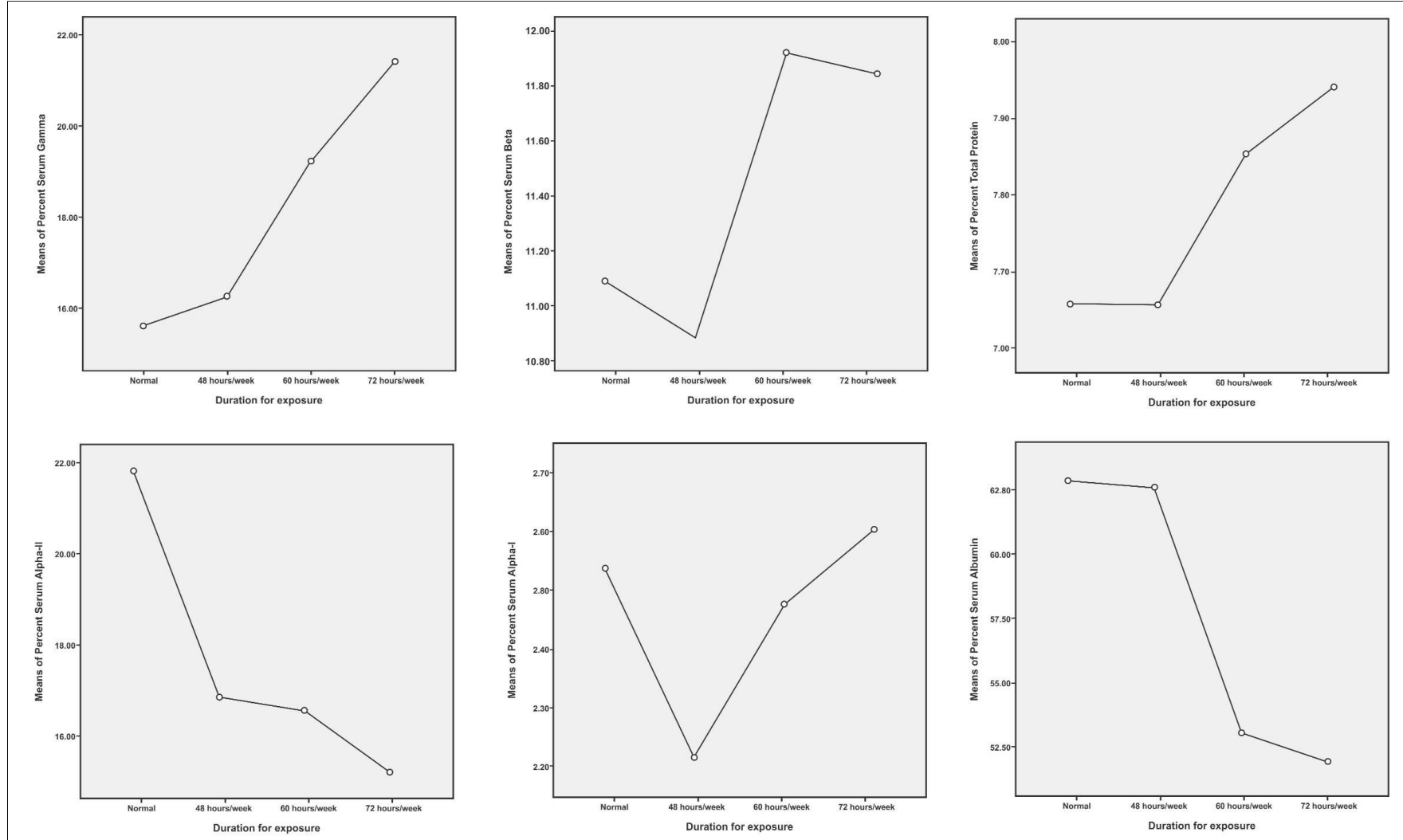

Figure 1: Variations in electrophoretic serum proteins fraction (Albumin, Alpha1, Apha2, Beta and Gamma). Expression patterns with respect to duration of radiation exposure as compared to control have been presented.

moderate nature of relationship. Albumin and alpha1 had an inverse relationship; while the relationship between alpha1 and gamma globulins was direct ( $r=44 \%$, Table II).

\section{DISCUSSION}

X-radiation technicians who do not follow the radiation protection protocol, are considered as the most appropriate candidates for findings the effects of low-dose radiations exposures over the longer periods of time.12 So investigating these occupationally workers is an important source of gaining information about exposure to IR of low doses and related risk assessment.13,14 Radiations-induced chronic oxidative stress leads to various pathological effects. ${ }^{15}$ With this background information, the authors intended to investigate the antioxidant capacity and expression pattern of different serum proteins in those radiology technicians.

The results of this study revealed significantly low TEAC in X-ray technicians. The significant reduced TEAC values were observed in X-ray technicians who work for 72 hours per week. Similar findings have been reported in previous studies, serum total antioxidant level (TAL) in radiology workers were found to be reduced as compare

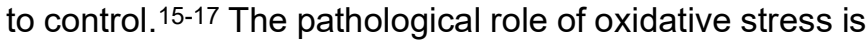
well established and IR-induced oxidative stress lasts for longer duration of time in the body is called as late effects. In an animal study, significantly elevated oxidative stress was also observed in mice after six months of exposure to IR. ${ }^{18}$ Similarly, elevated oxidative stress was also observed in mice in post-irradiated lungs. It is confirmed that ROS disrupts biomolecules to produce detrimental effects such as cancer.19,20 Low doses of radiation do not produce direct deterministic effects like skin burn or erythema. However, its longer exposure causes certain types of neoplasms. ${ }^{16}$ The results of current study confirmed a negative correlation between radiation work duration and oxidative stress. The oxidative products of plasma proteins was also elevated in radiology staff of hospital. ${ }^{19}$ Previous studies have reported a significant high level of lipid peroxidation with reduced activity of erythrocyte glutathione peroxidase, superoxide dismutase and catalase in erythrocytes of X-rays workers as compared to control.21

The radiations exposure can also alter the expression of serum proteins. Therefore, protein expression profiling has been quite helpful to develop radiation-induced serum biomarkers. ${ }^{22}$ In current study, the largest fraction, albumin is found to be declined (hypoalbuminemia) in X-ray technicians, those having work duration of 60 and 72 hours per week (Table I). Previous studies have reported hypoalbuminemia in radiology workers and attributed to the radio-sensitivity of liver, that leads to hepatocytes damages which cause reduced synthesis of albumin in liver. ${ }^{23}$ Acute inflammatory conditions also decreases the production of albumin by liver, because interleukin- 6 engages hepatocytes in increased productions of acute-phase reactants i.e. C-reactive protein, complement factors and serum amyloid A. ${ }^{24}$ In animal 
studies, serum albumin levels was declined after irradiation on total body of rats. ${ }^{25}$

The alpha1, alpha 2 and beta globulins were in normal ranges in both, X-ray technicians and control groups. Technicians of longer work duration 60 and 72 hours per week, demonstrated most frequent abnormal bands in gamma region (Table I). In animal model studies, elevated gamma globulin fraction was observed in cattle after X-ray irradiation on whole body.22,24 In radiology staff, the status of serum immunoglobulins, which perform natural protective functions of body, was found to be significantly elevated.21 Low dose radiationinduced enhanced Th2 immune response was observed in X-ray technicians indicating increased immunoglobulin $(\lg G, \lg \mathrm{A}$, and $\lg \mathrm{M})$ production.20 In the current study, it is observed that long-term exposure to low doses of $X$-radiations increases serum gamma globulin levels, comprised of immunoglobulins and C-reactive protein, indicates a notable impact on immune system and development of inflammations in the body of radiology workers. The authors recommended the adaptation and implementation of technical preventive measures by the X-rays department workers such as wearing appropriate protective equipment, like lead apparel, lead goggles, thyroid shield etc. It is also suggested that the X-ray technicians must undergo periodic medical surveillance tests to identify the more susceptible workers.

\section{CONCLUSION}

The outcome of current study revealed that the long term exposure (60 to 72 hours per week) to low doses of $X$-rays may cause increase in oxidative stress and changes the expression pattern of albumin and gamma globulins, which in clinical terms may be correlated with acute/chronic inflammation.

\section{REFERENCES}

1. Meenu V, Sonam, Ayub S. Biological effects of X-rays on X-ray technicians. IJIRSET 2016; 5:8512-6.

2. Gráinne $O B$, Lourdes $C G$, Matthäus $M$, Jakub $G$, Michael $A$, Matthias $\mathrm{P}$, et al. FDXR is a biomarker of radiation exposure in vivo. Sci Rep 2018; 8:684.

3. Zbikowska HM, Antosik A. Irradiation dose-dependent oxidative changes in red blood cells for transfusion. Int $J$ Radiat Biol 2012; 88:654-60.

4. Borek C. Dietary antioxidants and human cancer. Integr Cancer Ther 2004; 3:333-41.

5. Cardoso MJL, Machado LHA, Moutinho FQ. Sinaisclínicos do linfomacanino. Arch Vet Sci 2004; 9:25-9.

6. Pouget JP, Mather SJ. General aspects of the cellular response to low- and high-LET radiation. Eur J Nucl Med 2001; 28:541-61.

7. Dragoslav N, Kwan Ngok Yu. Alpha-particle influence in radiobiological experiments. J Radiat Res 2017; 58:195-200.

8. United Nations Scientific Committee on the Effects of Atomic Radiation. Sources and effects of ionizing radiation. UNSCEAR 1994 Reports. New York: 1994.
9. Birben E, Sahiner UM, Sackesen C, Erzurum S, Kalayci O. Oxidative stress and antioxidant defense. World Allergy Organ J 2012; 5:9-19.

10. Bamdad R, Mahdi BM, Seyed-Ali A. Evaluation of the serum total antioxidant level and hematological indices in healthy workers exposed to low radiation doses: A significant increase in platelet indices. Phamacology Online 2014; 1:63-7.

11. Benzie IF, Strain JJ. The ferric reducing ability of plasma (FRAP) as a measure of "antioxidant power": The FRAP assay. Anal Biochem 1996; 39:70-6.

12. Malekirad AA, Ranjbar A, Rahzani K, Pilehvarian AA, Rezaie A, Zamani $\mathrm{MJ}$, et al. Oxidative stress in radiology staff. Environ Toxicol Pharmacol 2005; 20:215-8

13. Kawagoshi, Shiomi N, Takahashi H, Watanabe Y, Fuma S, Doi K, et al. Chromosomal aberrations in large Japanese field mice (apodemusspeciosus) captured near Fukushima Dai-ichi nuclear power plant. Environ Sci Technol 2017; 51:4632-41.

14. Kadam SB, Shyama Sk, Kumar PMK, Dcosta A, Almeida VG. Cytogenetic analysis on the yields of chromosomal aberrations induced by the scattered doses of $\gamma$-radiation. $J \mathrm{Nucl}$ Med Radiat Ther 2016; 7:445-50.

15. Linet MS, Kim KP, Miller DL, Kleinerman RA, Simon SL, Berrington DE, et al. Historical review of occupational exposures and cancer risks in medical radiation workers. Radiat Res 2010; 174:793-808.

16. Kayan M, Naziroglu M, Celik O, Yalman K, Köylü H. Vitamin C and $E$ combination modulates oxidative stress induced by $X$-ray in blood of smoker and nonsmoker radiology technicians. Cell Biochem Funct 2009; 27:424-9.

17. Klucinski P, Wójcik A, Grabowska-Bochenek R, Gminski J, Mazur B, Hrycek A, et al. Erythrocyte antioxidant parameters in workers occupationally exposed to low levels of ionizing radiation. Ann Agric Environ Med 2008; 15:9-12.

18. Tapio S, Hornhardt S, Gomolka M, Leszczynski D, Posch A, Thalhammer $S$, et al. Use of proteomics in radiobiological research: Current state of the art. Radiat Environ Biophys 2010; 49:1-4.

19. Mornex F, Gérard F, Ramuz O, Van Houtte P. Late effects of radiations on the liver. Cancer Radiother 1997; 1:753-9.

20. Graham A, Charles JM. A role for soluble IL-6 receptor in Osteoarthritis. J Funct Morphol Kinesiol 2017; 2:27.

21. William M, Lydiatt MD, Snehal G, Patel MD, Brian O, Sullivan MD, et al. Head and neck cancers - major changes in the American joint committee on cancer eighth edition cancer staging manual. CA Cancer J Clin 2017; 67:122-37.

22. Ilona MG, Kalina I, Penkova I, Tankova R, Delyana Y, Panova JN, et al. Assessment of some immune parameters in occupationally exposed nuclear power plant workers flow cytometry measurements of $\mathrm{t}$ lymphocyte subpopulations and immunoglobulin determination. Dose Response 2015; 13: 1559325815 611901.

23. Shahid S, Mahmood N, Chaudhry MN, Sheikh S, Ahmad N. Assessment of impacts of hematological parameters of chronic ionizing radiation exposed workers in hospitals. FUUAST J Biol 2014 ; 4:135-46.

24. Kusunoki Y, Hayashi T, Hakoda M. Long-term effects of A-bomb radiation on the immune system: Beyond a half century. RERF Update 2004; 15:7-18.

25. Shahid S, Masood K. Assessing liver proteins and enzymes of medical workers exposed to ionizing radiation (IR). Clin Exp Med 2018; 18:89-99. 